\title{
Factors of community participation that explain the benefits of ecotourism
}

\author{
María Cristina Sosa* \\ Universidad Autónoma de Occidente (México) \\ Ludger Brenner** \\ Universidad Autónoma Metropolitana (México)
}

\begin{abstract}
The sustainability of ecotourism initiatives represents a major challenge. The aim of this study is to enhance our understanding of how community participation in ecotourism management can contribute toward achieving more sustainable results by identifying key factors that make it possible to potentiate a broader range of economic, social and environmental objectives. Based on the theory of collaborative planning and the strategic focus of community tourism, our work adopted a mixed approach to compare and explain the differences between two local cooperatives on the coast of the state of Nayarit, Mexico. The results reveal statistically-significant differences between the benefits obtained through ecotourism and identify the factors that foment active community participation by local residents that, in turn, generates positive correlations with those benefits. Findings were supported by qualitative interviews with external informants. Our conclusion is that the level of benefits obtained can be reasonably explained by a set of six key factors.
\end{abstract}

Keywords: Ecotourism; Community Tourism; Management; Community Participation; Sustainability.

\section{Factores de participación comunitaria que explican los beneficios del ecoturismo}

Resumen: La sostenibilidad de las iniciativas ecoturísticas representa un importante desafío. El propósito de este artículo es ayudar a la comprensión de cómo la participación comunitaria en la gestión del ecoturismo puede contribuir a alcanzar resultados más sostenibles en la actividad, identificando los factores claves a través de los cuales se puede potenciar un mayor alcance de objetivos económicos, sociales y ambientales. Con base en la teoría de la planeación colaborativa y el enfoque estratégico del turismo comunitario, esta investigación emplea el enfoque mixto para comparar y explicar las diferencias entre dos cooperativas locales de la costa del estado de Nayarit, México. Los resultados revelaron diferencias estadísticamente significativas entre los beneficios obtenidos con ecoturismo, así como en los factores que impulsan la participación comunitaria activa de los residentes locales, los que a su vez arrojaron correlaciones positivas con los beneficios. Tales hallazgos fueron reforzados con entrevistas cualitativas a informantes externos, concluyendo que el nivel de beneficios logrados puede ser explicado razonablemente por un conjunto de seis factores claves.

Palabras Clave: Ecoturismo; Turismo comunitario; Gestión; Participación comunitaria; Sostenibilidad.

\section{Introduction}

Interest in nature-based tourism (NBT) and ecotourism has increased considerably in recent years. Ecotourism is identified as a normative concept that entails obligations to contribute to the objectives of environmental conservation and education, as well as local socioeconomic development, in order to promote sustainable tourism activities. The participation of receiving communities in decision-making and the implementation and development of ecotourism projects has been the topic

\footnotetext{
* Universidad Autónoma de Occidente (México); E-mail: macrisol@gmail.com; https://orcid.org/0000-0003-1352-4826

** Universidad Autónoma Metropolitana (México); E-mail: bren@xanum.uam.mx; https://orcid.org/0000-0003-1052-9007
} 
of numerous studies (Okazaki, 2008; Sebele, 2010; Lee, 2013) conducted to elucidate the importance of this element for achieving the stated objectives. The management model known as "community tourism" assigns local residents control over decisions related to the project, for it recognizes that direct community involvement increases the probability that projects will be successful (Murphy, 1985; Cheung, 2015).

There are numerous cases of community tourism in Mexico. One study shows that public policies in support of NBT and ecotourism in the period 2006-2012 involved 17 institutions with 57 programs, $52 \%$ of which stipulated community management (López and Palomino, 2014). However, it argues that despite such efforts, this strategy has not been particularly successful in combatting poverty and marginalization in rural areas. Situations like this have ignited diverse debates regarding community participation in the management of tourism activity and its effectiveness in achieving the benefits that ecotourism seeks to provide. While 'lack of participation' is identified as the second-most important cause of failures to reach proposed objectives (Krüger, 2005), studies have emphasized the difficulties that arise, and must be overcome, in order to achieve such participation. They underscore such factors as local residents' poor understanding of the objectives of ecotourism, and insufficient training (Jamal and Getz, 1994; Li, 2006; Sebele, 2010). Orellana (2014) adds that participation is no guarantee that social objectives will be satisfied, while earlier studies warn of the role of distinct types of participation (Fiorello and Bo, 2012) that vary according to the scope of involvement of local actors, but consider local participation a requirement for reach proposed goals. Characterizing forms of participation and their importance for the goals of ecotourism are just two of the topics addressed in this article.

The aforementioned discussions reveal a persistent lack of clarity regarding the role and effectiveness of community participation in relation to achieving the objectives of ecotourism. In fact, they could lead one to think that results may be conditioned by features or elements of processes of participation; specifically, human and organizational factors that may favor or limit initiatives of this kind.

The present study was conducted in two communities on the coast of the state of Nayarit, Mexico, a region with huge potential for ecotourism development (SECTUR and UAN, 2014). Two local cooperatives offer tourism services in the municipalities studied. Their functioning, activities and control of natural spaces facilitate a comparative analysis designed to detect differences in members' participation and the range of benefits that people expect ecotourism to generate. Our approach integrates the theory of collaborative planning (Healey, 1997) with a strategic focus on community tourism (Murphy and Murphy, 2004) in order to respond to the following research question: What factors of community participation favor achieving economic, social and environmental benefits through ecotourism? This issue is addressed through four more specific questions:

1) What are the principle differences between these two cooperatives in terms of the economic, social and environmental benefits obtained?

2) What are the key differences between them in relation to factors of participation community?

3) What factors of participation are key for increasing the benefits of ecotourism?

4) To what degree can the total level of benefits achieved be explained by the multiple correlation of the factors of participation?

Previous studies have addressed these phenomena from diverse theoretical angles; for example, Clausen and Gyimóthy (2016), who analyzed citizen participation in the development of sustainable tourism using the theory of governance, or Fiorello and Bo (2012), who examined the participation of local residents in decisions involving ecotourism through the theory of "empowerment" to find that various degrees of empowerment may exist. Numerous analyses have described the importance of certain factors (elucidated below) for fomenting participation during collaborative decision-making processes (Jamal and Getz, 1995; Guevara, 1996; McCool, 2009; Sebele, 2010, Fiorello and Bo, 2012). However, research designed to measure the relations that exist among these factors and the specific objectives of ecotourism have been largely overlooked. In addition, this paper highlights the comparative nature of our analysis method, deepening our understanding of the observed differences, and applying an integrative conceptual approach that combines the theory of collaborative planning (Healey, 1997) with the strategic approach of community tourism (Murphy and Murphy, 2004) to expand the results. 


\section{Normative characterization of ecotourism}

Ecotourism management is plagued by a problem of conceptual understanding, for it is commonly considered equivalent to nature-based tourism, alternative tourism or sustainable tourism, with a limited appreciation of what this activity actually promises visitors and destinations (Goodwin, 1996; Orams, 2001); to avoid confusion, it is appropriate set out from a normative focus centered on the desirable effects of ecotourism (Blamey, 2001; Sosa, 2018) that conceives this activity as one designed to offer a specific set of economic, sociocultural and environmental benefits that have been identified through numerous studies (Li, 2006; Morera, 2008; Krüger, 2008; Sebele, 2010; Fiorello and Bo, 2012; Jalani, 2012; Agüera, 2014; Das and Chatterjee, 2015). Economic benefits include the effective generation of employment and income, diversification, productive use of lands that generate low agricultural yields, and local commercial ventures, among others. At the same time, these economic benefits must construct a scenario that favors generating sociocultural benefits, such as transportation and communications infrastructure, strengthening a destination's cultural heritage, inclusive work practices (i.e., for women and young people), improvements in education, and enhanced quality of life. Finally, some of the income obtained from entry fees, charges, donations, and auxiliary goods and services (accommodation, souvenirs, gastronomy, etc.) should be used to produce environmental benefits, such as conservation efforts and education through experiences of contact with nature (Goodwin, 1996).

These benefits are not generated independently, as there is an interdependence between them that has been pointed out by theorists such as Goodwin (1996) and confirmed later (Das and Chatterjee, 2015; Sosa, 2018). Hence, is possible to predict that an adequate management will be most likely foster the generation of the aforementioned benefits.

\section{Forms of community participation}

According to Taylor (1995), the concept of community participation in tourism development has been placed at the center of the debate around sustainability. Analysts have made contributions that clarify the type of participation required in different scenarios (Tosun, 2006; Fiorello and Bo, 2012; Orellana, 2014), by deducing that certain forms of participation cannot guarantee achieving the normative objectives of ecotourism. The most widely-recognized model is Arnstein's "citizen participation scale". Table 1 shows the correspondence between this model and other typologies of community participation. What we learn through these typologies is that distinct levels of participation can exist, including some that do not involve any 'genuine' participation by local actors. As Hall (1999) points out, we cannot ignore the reality that power may lurk behind facades of "collaboration", seeking to promote private interests through manipulation. Table 1 also shows coincidences among these varied classifications in the sense that they all set out from lower levels and move upwards towards genuine forms of participation that pertain to the upper levels of the scale. Jamal and Getz (1995) have suggested two categories for application in studies of tourism, arguing that it is possible to merge all forms of "non-genuine" participation in a category called "Passive Participation" and all forms of genuine participation in the category "Active Participation".

Active participation by a local community has been defined as "empowering people to mobilize their own capacities, to become social actors rather than passive subjects, to manage their resources, to take decisions and to control the activities that affect their lives" (Cernea, 1991, cited by Fernández, 2011: 39). For this author, the main objective of this type of participation is to allow local populations to overcome social and economic marginalization. It also entails consensual decision-making that directly impacts their families, customs and quality of life, as well as acting in consequence to transform their reality. Ramos and Prideaux (2014) add that this fosters actors' self-confidence and self-esteem. It also allows us to understand that in contexts of community participation, the economic, social and environmental objectives of ecotourism can only be achieved through the active participation of actors. 
Table 1: Correspondence among typologies of community participation.

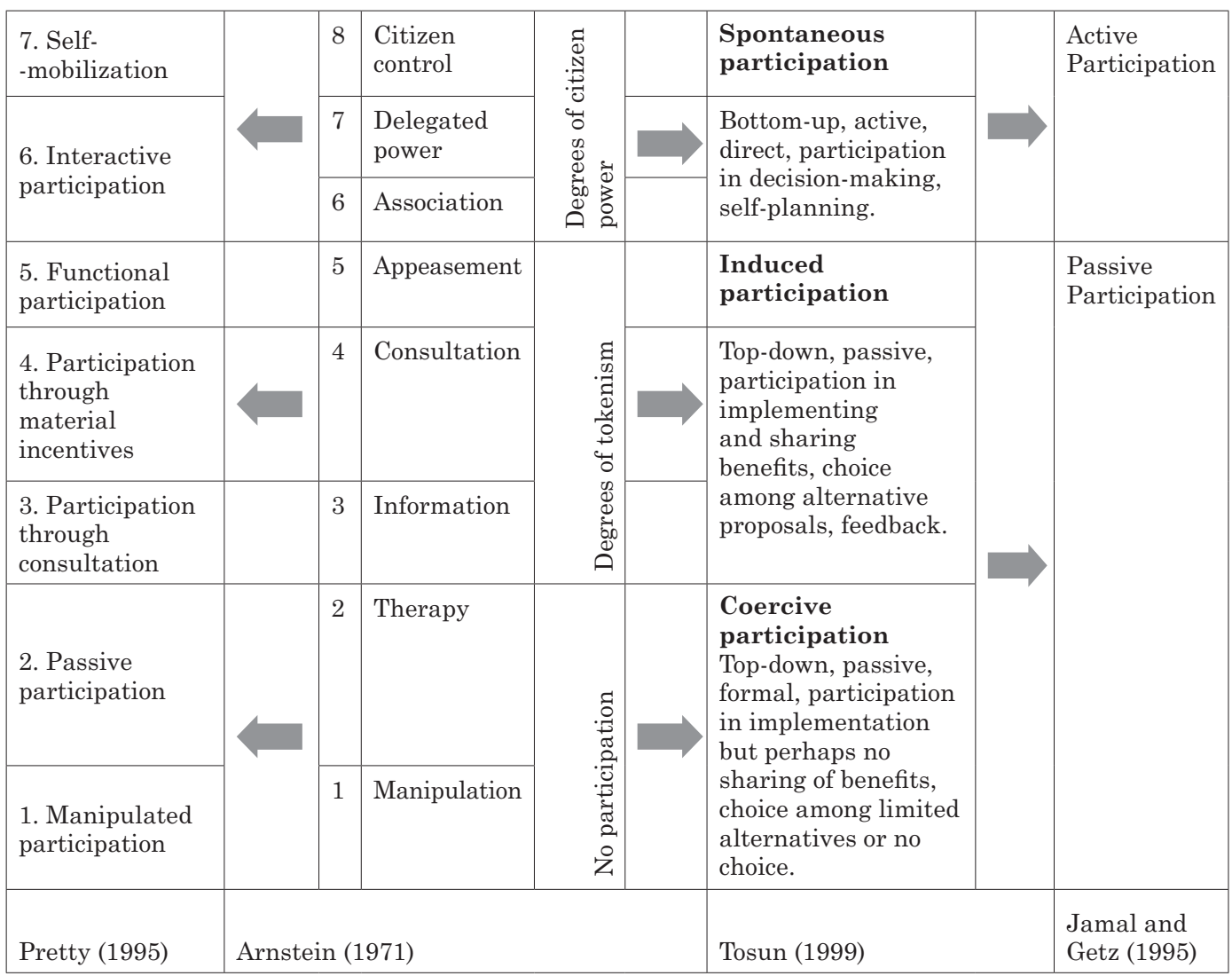

Source: adapted from Tosun (2006).

Note: arrows signal concordance between distinct levels.

\section{Factors that favor active community participation}

To understand the conditions in which active community participation develops, one effective theory is called collaborative planning, an approach that makes possible to conceive community management as a social process in which participants actively construct forms of thinking, evaluating and acting (Healey, 1997). Thus, it refers to a learning process strengthened through interaction that supports decision-making and implementation. This focus on collaboration incorporates the participation of multiple actors to address and resolve problems under conditions marked by complexity, interdependence and uncertainty that demand developing collective strategies to optimize benefits for all interested parties (Trist, 1977, cited by Jamal and Getz, 1995).

Several theoretical models of collaborative planning are applicable to tourism, mainly those that focus on forms of decision-making processes that involve the community as a whole (Selin and Chávez, 1995; Guevara, 1996; Hall, 1999; Kernel, 2005; Okazaki, 2008). Healey (1997) explains this as a process designed to construct consensus, emphasizing that this is achieved through the reconstruction of a public sphere where it becomes possible to debate and resolve collective concerns more inclusively. Under this approach factors are identified that could favor active participation in ecotourism; factors that can be reinforced during collaborative processes (Healey, 1997) due to interdependence that exists among these elements. These factors can be grouped into two types: a) human factors that facilitate 
active involvement in constructing consensus; and b) organizational factors that may favor or impede collaborative processes (Table 2).

Further, Murphy and Murphy (2004) add that the community is better positioned to achieve a community focus on tourism if guided by the principles of strategic management, where developing a shared vision and linkages with other stakeholders (universities, research centers, external advisers, NGOs) is granted importance and can be included among the organizational factors to be analyzed (Table 2). The existence of a shared vision is related to processes of active participation by the parties involved in dialogues and the construction of consensus (Murphy and Murphy, 2004). Although community management is deemed possible in this approach, communities will still require some type of external collaboration or association (Nault and Stapleton, 2011). According to Murphy and Murphy (2004), links to other stakeholders entail "thinking outside the box", incorporating external groups, and developing broader perspectives.

Table 2: Factors that favor active community participation.

\begin{tabular}{|l|l|}
\hline \multicolumn{1}{|c|}{ Human factors } & \multicolumn{1}{c|}{ Organizational factors } \\
\hline $\begin{array}{l}\text { Valuing local assets: recognizing the innate values } \\
\text { of the community's natural and cultural attractions } \\
\text { (Murphy, 1985; Guevara, 1996). }\end{array}$ & $\begin{array}{l}\text { Leadership: the leader's performance as } \\
\text { representative and main conductor of group } \\
\text { actions; entails the ability to manage resources, } \\
\text { motivate innovation, facilitate dialogue, and } \\
\text { share power among actors, etc. (Gray, 1989, cited } \\
\text { by Jamal and Getz, 1995; Gunn and Var, 2002; } \\
\text { Murphy and Murphy, 2004; Nault and Stapleton, } \\
\text { 2011; Fahmi et. al, 2016) }\end{array}$ \\
\hline \multirow{2}{*}{$\begin{array}{l}\text { Perception of individual and community benefits: } \\
\text { recognizing the interdependence among actors, and } \\
\text { that their actions will generate collective benefits } \\
\text { (Jamal and Getz, 1995; Kernel, 2005) }\end{array}$} & $\begin{array}{l}\text { Spaces for learning: the presence of spaces or } \\
\text { opportunities that foster interaction, acquiring } \\
\text { knowledge, and developing skills (Jamal and Getz, } \\
\text { 1995; Guevara, 1996; McCool, 2009; Fiorello and } \\
\text { Bo, 2012; Fahmi et. al, 2016). }\end{array}$ \\
\hline \multirow{2}{*}{$\begin{array}{l}\text { Shared vision: congruence between the aspirations } \\
\text { of the parties regarding the desired future of the } \\
\text { ecotourism project (Jamal and Getz, 1995; Murphy } \\
\text { and Murphy, 2004) }\end{array}$} \\
\cline { 2 - 2 } & $\begin{array}{l}\text { Linkages with other stakeholders: relations with } \\
\text { external organizations for managing tourism } \\
\text { activities and natural resources (Jamal and Getz, } \\
\text { 1995; Fiorello and Bo, 2012). }\end{array}$ \\
\hline
\end{tabular}

Source: elaborated by the authors.

Note: factors selected by meta analysis technique for developing the study's indicators (Annex 2).

\section{The study area}

Our research was conducted in two communities of Nayarit state, on the Pacific coast in western Mexico. We studied tourism cooperatives: San Blas (hereinafter S.B.) and Rincón de Guayabitos (hereinafter R.G.). These localities are separated by a distance of $90 \mathrm{~km}$ (Figure 1). These organizations are governed by General Law of Cooperative Societies (LGSC, 2009), that defines cooperatives as "a form of social organization made up of individuals, based on common interests and principles of solidarity, self-effort and mutual aid; with the purpose of satisfying individual and collective needs, through the performance of economic activities of production, distribution and goods and services consumption" (article 2).

The latest available data about demand are from 2017, when 2,626,755 tourists were registered in the state of Nayarit, $50.6 \%$ of which correspond to Tepic, San Blas and Rincón de Guayabitos, and $49.4 \%$ to Nuevo Vallarta (INEGI, 2017). 
Figure 1: location of the study area.

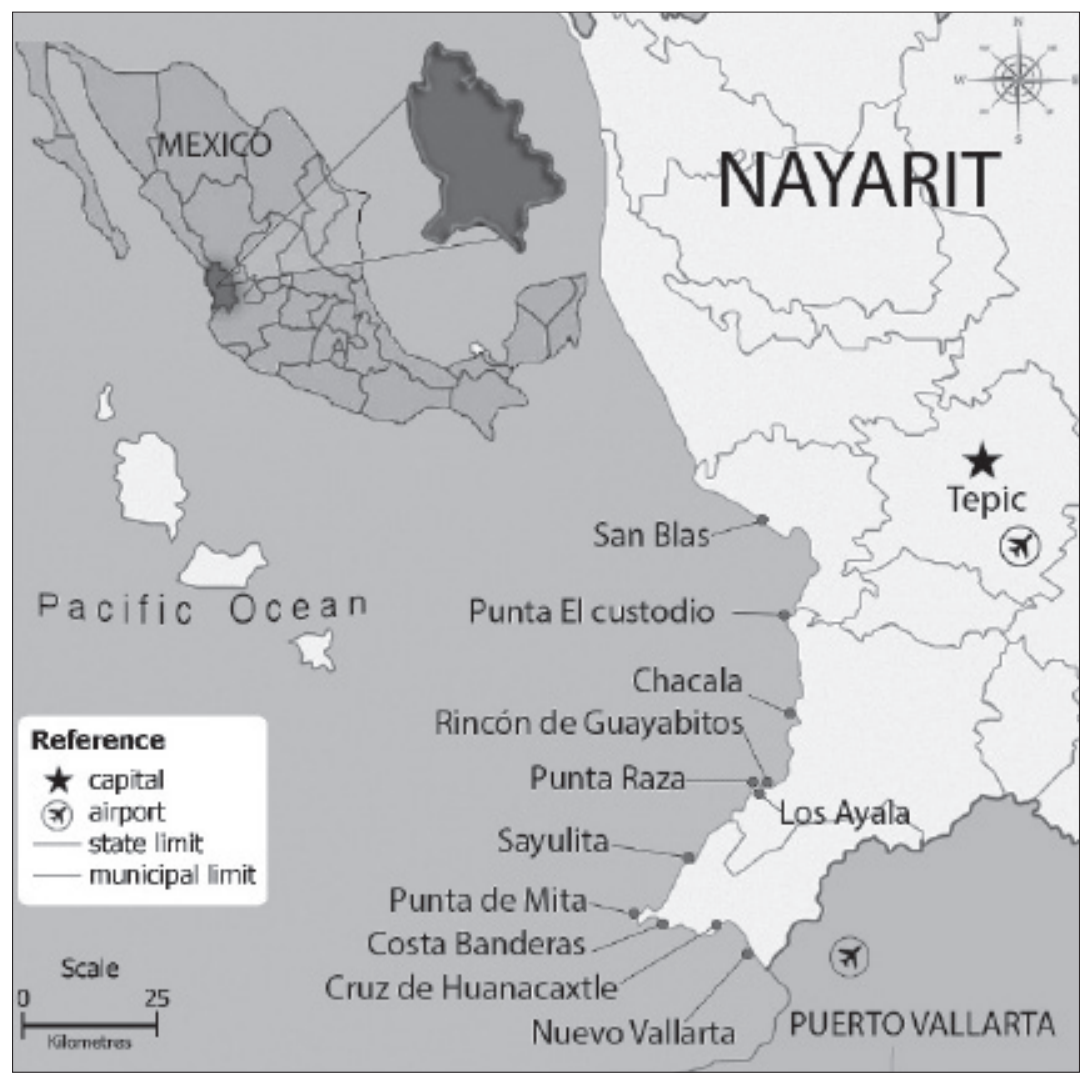

The S.B. cooperative uses a wetland ecosystem (Figure 2), in an area of 5,533 hectares declared a RAMSAR site. It offers boats excursions for bird-watching, or into the interior of a mangrove reserve with stops at a crocodile park and a natural pond filled with fish where visitors can swim. Three commercial locales operated by members' families offer regional products, snacks and beverages. In addition to its members, S.B. employs 11 men as boat-drivers (additional details in Annex 1). One important feature of this cooperative is that several of its founding members continue to participate in the activities. S.B.'s organizational structure and decision-making comply with Mexican law, as it has a General Assembly as the maximum authority for establishing accords among members. Usually, two ordinary assemblies and two extraordinary assemblies are held annually, but the Administrative Board meets monthly and has the faculty to take certain decisions without needing to call an assembly. ${ }^{1}$

Regarding the work performed by the boat-drivers, we found that they are stationed at one of two quays, where visitors receive information on the excursions from an individual -usually one of the cooperative's directors- who charges them for their tickets. The boats go out following a set order. At the end of the working day, the administrators recoup the percentage of the take that corresponds to the cooperative's common fund. The remaining income is then shared out equally among members. After that, the cooperative charges each driver for the fuel it had supplied and applies any penalizations in which he may have incurred. Those fines are also deposited in the common fund. Daily work activities include tourism services and activities performed to maintain and conserve the natural environment, as well as a revolving work schedule during low seasons when scarce demand means that not all boat-drivers are required. This cooperative assumes all expenses, including purchasing, maintaining and repairing the boats and docks, buying lifejackets and other safety gear, insurance for visitors, and fuel, etc. It has permits to utilize 25 boats in the Reserve, with a limit of 12 people per boat. 
Figure 2: The entrance to the natural reserve (left). Boarding point of the S.B. cooperative (right).

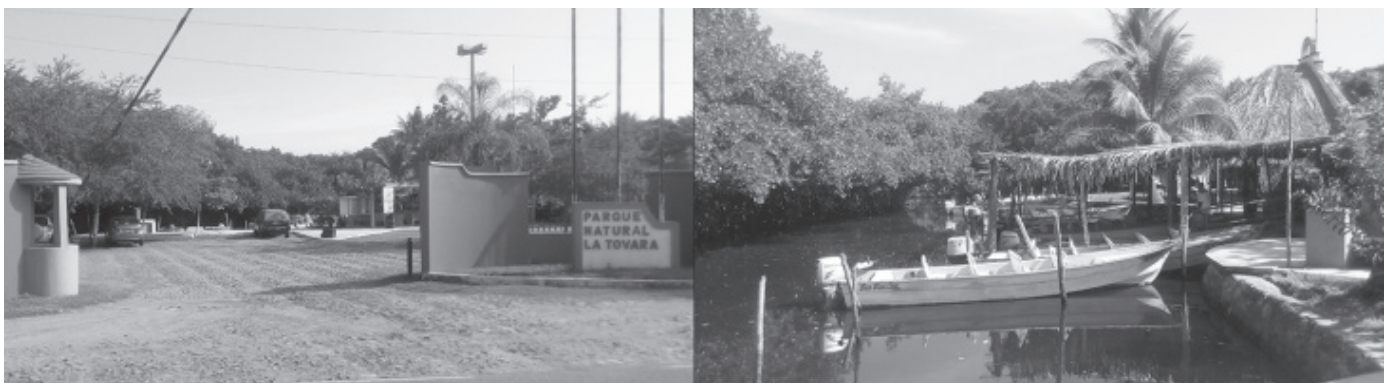

The R.G. cooperative uses a marine ecosystem (Figure 3), offering humpback whale watching, sport fishing, and visits to "Coral Island", a natural reserve of approximately 12 hectares protected by the community, including 95 meters of certified clean beach, where visitors can scuba-dive and snorkel. It also offers diverse complementary activities. ${ }^{1}$ Services on the island are provided and supervised regularly by one cooperative member and his family. The cooperative stipulates that after three years this responsibility passes to a different member, whose family has the right to benefit economically from the services it offers.

In addition to members, this cooperative employs around 70 workers. Their functions include serving as boat captains, ticket-sellers, secretaries and laborers on the island. Another 30 free-lancers work as promoters, offering excursions in exchange for a commission. Finally, there are 20 seasonal workers, including other promoters and assistants who participate in activities during seasons with high demand. Today, none of the founding members are active; their rights have passed to their sons or daughters. R.G. holds six ordinary assemblies a year, at the beginning and end of each high season (i.e., summer vacations, winter vacations and Easter), as well as one or two extra meetings per month, according to need and any urgent situations that may arise.

Work at R.G. is based on the independence and responsibility of individual members for their boat and equipment. Each one keeps the income earned daily from the excursions they conduct, but must respect the work guidelines established by the cooperative covering such matters as the condition of their boats, regulatory aspects (e.g. first aid kit, lifejackets, oars, mirrors, radio, whistle and flares, among other gear), insurance for visitors, tariffs, and rotation through launching sites, etcetera. Organization is based on a series of nine launch areas. Members must rotate through these nine sites during the week and maintain strict control over two potential situations of conflict: a) the boats can only travel to determined zones, a measure that has reduced the number of accidents; and b) the rotation system ensures that all members have equal opportunities to attract clients, thus reducing internal disputes.

The fund for managing this cooperative comes from the sale of the bracelet that all tourists must wear in order to visit Coral Island, where the cooperative's boats enjoy rights of exclusive access. There is no limit on the number of boats that can dock at the island, but the cooperative imposes a two-hour time limit on visits, and clearly delimits the zones where boats can dock.

Figure 3: Installations of the R.G. Cooperative (left). Boats around Coral Island (right).

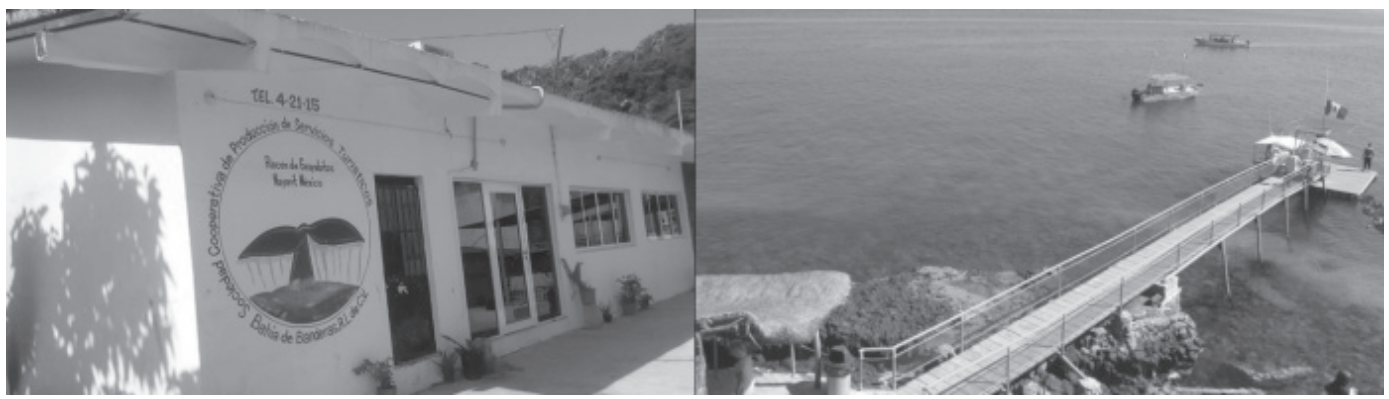




\section{Materials and Methods}

We applied a comparative study method with mixed methods. Selection of the case studies was by convenience after preliminary evaluations to determine compliance with a series of criteria established in the literature. ${ }^{1}$ After two exploratory visits to each community to assess compliance with the criteria and another six pilot surveys applied to establish the precision of the measurement instrument, final fieldwork was conducted in November-December 2017. To gather quantitative data, we applied structured surveys based on a Lickert scale format and open-ended question to 16 members ${ }^{2}$ of each cooperative in an effort to obtain their assessments of the benefits obtained and the factors described in Table 2. To measure the participation factors and strategic principles, a Lickert scale was designed, this one offering five levels of evaluation of a series of positive and negative statements. ${ }^{3}$ Options for the positive statements ran from 1= "Strongly disagree", the lowest possible score, to $5=$ "Strongly agree", the highest possible score. This system was inverted for the negative expressions, as $1=$ "Strongly agree" represented the lowest possible score, and $5=$ "Strongly disagree" indicated the highest possible score. To measure the benefits of ecotourism, we carefully elaborated questions ${ }^{4}$ for three dimensions -economic, social and environmental-providing three answer options for each one. The options were assigned scores of 1,2 or 3 , where $1=$ less favorable, and $3=$ more favorable. Because several statements and questions were used to measure each element, it was necessary to construct an index value for each element involved (Babbie, 2000). This was performed by totaling the scores for each cooperative, and then comparing the sum to the ideal (normative) value; that is, the maximum possible score (100\%). This method follows a principle suggested by Ponce (2012) for evaluating the sustainability of ecotourism, which consists in comparing, simultaneously, two or more alternative systems in relation to a reference system. Obtaining these indices required normalizing the scores by incorporating the maximum and minimum values from the scales in the expression: $\mathrm{X}^{\prime}=(\mathrm{X}-\mathrm{X} \min ) /(\mathrm{Xmax}-\mathrm{Xmin})$, where $\mathrm{X}$ is the original value, and $\mathrm{X}^{\prime}$ the normalized value. The next step was to total the normalized values and multiply by 100 .

The statistical significance of the differences observed was analyzed using a Student's t test ${ }^{5}$ for two independent samples with $n 1=n 2=16$ and $\alpha=0.05$, followed by Chi-square tests ${ }^{6}$ and correlation of the factors with benefits obtained for $n=32$. Finally, a multiple lineal regression analysis was performed to determine the impact of the interaction of all the factors at once on total benefits. ${ }^{7}$ All these procedures were run using SPSS 24 software for statistical analysis.

Turning to the qualitative data, we employed field-based observation, documental review, and semi-structured interviews with 10 key informants ${ }^{2}$ (government agents, local residents, representatives of private organizations) to gather their views on economic, social and environmental aspects of the two destinations, and of the cooperatives and their performance. Questions were phrased to contrast responses of informants not related to cooperative members, without resorting to pre-validated research since we apply data triangulation strategy (Ander-Egg, 2000). The criterion was to interview all possible actors based on the relevance and the snowball method. Nevertheless, we stopped interviewing when informants no longer provided additional information (Navarrete, 2000). These data were transcribed, coded and analyzed with Atlas.ti software ${ }^{8}$, using the strategy of integrating the qualitative information with explanations of the quantitative data.

\section{Results}

\subsection{Benefits of ecotourism}

Table 3 reveals that differences exist in relation to the benefits of ecotourism obtained. For each dimension, as well as for total benefits, the differences observed are statistically significant ( $p$-value $<0.05$ ), clearly indicating that the economic and environmental benefits present the largest differences. For economic benefits, S.B. scored a low level, while R.G. achieved a moderate score. For social and environmental benefits, S.B. reached a moderate level, and R.G. a high level. ${ }^{9}$ 
Table 3: Mean scores for the benefits of ecotourism.

\begin{tabular}{|l|c|c|c|c|c|}
\hline Benefits & S.B. & R.G & Maximum score & Difference of means & p-value* \\
\hline Economic & $30 \%$ & $59 \%$ & $100 \%$ & $29 \%$ & .003 \\
\hline Social & $54 \%$ & $70 \%$ & $100 \%$ & $16 \%$ & .047 \\
\hline Environmental & $50 \%$ & $76 \%$ & $100 \%$ & $26 \%$ & .000 \\
\hline Total benefits & $46 \%$ & $69 \%$ & $100 \%$ & $23 \%$ & .001 \\
\hline
\end{tabular}

*Student's t test for equality of means in independent samples.

Regarding economic benefits, Table 4 shows that over half of the members of S.B. gave low assessments for benefits 22 to $24,{ }^{10}$ while those of R.G. generated a medium score for benefit 22 and high scores for benefits 21,23 and 24 .

With respect to additional income (21), the information obtained indicates that in both cases income from the cooperative sufficed to cover basic needs, but that people performed complementary activities.

For benefit 22 (complementary assistance for illness, subsidies, school scholarships, etc.), most members of S.B. stated that they have never obtained such gratuities, but that members can apply for cash loans from the common fund, with payment deducted from their earnings. Members did not recall having received any benefit from a profit-sharing scheme. In this regard, R.G. once again occupied a medium position, as members indicated that they have received such benefits on some occasions, and emphasized that profits have been shared.

With respect to social benefits, R.G. received higher evaluations than S.B. for the number of women involved in economic activities (26), improvement of skills (27) and interaction with other people (28).

In terms of environmental benefits, the largest differences were found in actions taken to prevent environmental contamination (30), enhance the natural spaces where activities are carried out (32), and informing and making tourists aware of the need to care for natural resources (34). Here, S.B. was positioned primarily in the medium category, but R.G. reached the high category.

Table 4: Comparative evaluation of economic, social and environmental benefits.

\begin{tabular}{|c|c|c|c|c|c|c|}
\hline \multirow[b]{2}{*}{ Indicators } & \multicolumn{3}{|c|}{ S.B } & \multicolumn{3}{|c|}{ R.G } \\
\hline & Low & Medium & High & Low & Medium & High \\
\hline \multicolumn{7}{|l|}{ Economic benefits } \\
\hline 21= Additional income & $50 \%$ & $6.25 \%$ & $43.75 \%$ & $25 \%$ & $18.75 \%$ & $56.25 \%$ \\
\hline $22=$ Complementary benefits & $62.50 \%$ & $25 \%$ & $12.50 \%$ & $31 \%$ & $56.25 \%$ & $12.50 \%$ \\
\hline $23=$ Indirect employment & $75 \%$ & $18.75 \%$ & $6.25 \%$ & $25 \%$ & $31.25 \%$ & $43.75 \%$ \\
\hline 24= Direct employment & $56.25 \%$ & $18.75 \%$ & $25 \%$ & $13 \%$ & $31.25 \%$ & $56.25 \%$ \\
\hline \multicolumn{7}{|l|}{ Social benefits } \\
\hline 26= Women employed & $6.25 \%$ & $81.25 \%$ & $12.50 \%$ & $12.50 \%$ & $18.75 \%$ & $68.75 \%$ \\
\hline $27=$ Improvement of skills & $68.75 \%$ & $25 \%$ & $6.25 \%$ & $18.75 \%$ & $50 \%$ & $31.25 \%$ \\
\hline $28=$ Interaction & $18.75 \%$ & $50 \%$ & $31.25 \%$ & - & $50 \%$ & $50 \%$ \\
\hline $29=$ Community support & $25 \%$ & $37.50 \%$ & $37.50 \%$ & $6.25 \%$ & $56.25 \%$ & $37.50 \%$ \\
\hline \multicolumn{7}{|l|}{ Environmental benefits } \\
\hline $30=$ Reduced contamination & - & $93.75 \%$ & $6.25 \%$ & - & $37.50 \%$ & $62.50 \%$ \\
\hline $\begin{array}{l}32=\text { Enhanced natural } \\
\text { setting }\end{array}$ & $18.75 \%$ & $50 \%$ & $31.25 \%$ & - & - & $100 \%$ \\
\hline $\begin{array}{l}34=\text { Environmental } \\
\text { education }\end{array}$ & $6.25 \%$ & $81.25 \%$ & $12.50 \%$ & $12.50 \%$ & $37.50 \%$ & $50 \%$ \\
\hline
\end{tabular}

Note: see Construction and significance of indicators in Annex 2.A. 


\subsection{Factors that explain variations in the benefits of ecotourism}

The study identified the factors of community participation (Table 2) that related positively to the benefits of ecotourism. Table 5 displays differences between the two cooperatives in the condition of the factors analyzed. These differences are statistically significant ( $p$-value<0.05), and underscore that R.G. presents more favorable conditions because it approached more closely the maximum possible score. The factors that stand out for the size of the differences of means are Leadership, Spaces for learning, and Perception of individual and community benefits.

Table 5: Mean scores for the factors of active community participation.

\begin{tabular}{|l|c|c|c|c|c|}
\hline \multicolumn{1}{|c|}{ Factors } & S.B. & R.G & $\begin{array}{c}\text { Maximum } \\
\text { score }\end{array}$ & $\begin{array}{c}\text { Difference } \\
\text { of means }\end{array}$ & p-value* \\
\hline Evaluation of local assets & $69 \%$ & $87 \%$ & $100 \%$ & $18 \%$ & 0.001 \\
\hline $\begin{array}{l}\text { Perception of individual and community } \\
\text { benefits }\end{array}$ & $56 \%$ & $87 \%$ & $100 \%$ & $31 \%$ & 0.000 \\
\hline Leadership & $44 \%$ & $76 \%$ & $100 \%$ & $32 \%$ & 0.000 \\
\hline Spaces for learning & $44 \%$ & $80 \%$ & $100 \%$ & $36 \%$ & 0.000 \\
\hline Shared vision & $66 \%$ & $87 \%$ & $100 \%$ & $21 \%$ & 0.001 \\
\hline Linkages with other stakeholders & $49 \%$ & $69 \%$ & $100 \%$ & $20 \%$ & 0.003 \\
\hline
\end{tabular}

*Student's $t$ test for equality of means in independent samples.

Table 6 shows that the factors assessed correlate positively and significantly with the benefits of ecotourism. Leadership stands out for its high correlation with total benefits, while Shared vision, Spaces for learning, Evaluation of local assets, Perception of individual and community benefits and Linkages with other stakeholders all show moderate correlations.

Table 6: Correlation of factors with the benefits of ecotourism.

\begin{tabular}{|l|c|c|c|c|}
\hline Variable: Objectives & \multirow{2}{*}{ BENECO } & BENSO & BENAMB & \multirow{2}{*}{ BENTOTAL } \\
\cline { 1 - 4 } Variable: Factors & $0.629^{* *}$ & $0.585^{* *}$ & $0.692^{* *}$ & $0.710^{* *}$ \\
\hline Leadership & $0.514^{* *}$ & $0.627^{* *}$ & $0.688^{* *}$ & $0.679^{* *}$ \\
\hline Shared vision & $0.496^{* *}$ & $0.439^{* *}$ & $0.690^{* *}$ & $0.601^{* *}$ \\
\hline Spaces for learning & $0.591^{* *}$ & $0.442^{* *}$ & $0.512^{* *}$ & $0.577^{* *}$ \\
\hline $\begin{array}{l}\text { Perception of individual and community } \\
\text { benefits }\end{array}$ & $0.470^{* *}$ & $0.449^{* *}$ & $0.583^{* *}$ & $0.558^{* *}$ \\
\hline Linkages with other stakeholders & $0.358^{*}$ & $0.385^{*}$ & $0.369^{*}$ & $0.415^{* *}$ \\
\hline
\end{tabular}

$\mathrm{BENECO}=$ economic benefit, $\mathrm{BENSO}=$ social benefits, $\mathrm{BENAMB}=$ environmental benefit,

BENTOTAL= total benefits

** The correlation is significant at the level 0.01 (unilateral).

* The correlation is significant at the level 0.05 (unilateral).

The factor Leadership maintained a high correlation with the economic (0.629) and environmental (0.692) benefits obtained. The analysis of this factor evaluated the role of the cooperatives' directors and members of the Administrative Board, to identify styles of leadership considering the characteristics mentioned in Table 2. The largest differences were recorded for statements 6 and 7. 
Shared vision is the factor with the second-largest impact on total benefits, due to its high correlation with environmental (0.688) and social (0.627) benefits. The largest differences were found for statements 14 and 15.

Spaces for learning had its highest correlation with environmental benefits (0.690). Differences $>30 \%$ in favor of R.G. were recorded for three statements: 9, 10, 12.

Evaluation of local assets presents its highest correlations with economic (0.591) and environmental (0.512). benefits. The largest differences were for statements 1 and 2 .

Perception of individual and community benefits correlated to a higher degree with environmental benefits (0.583), followed by economic benefits (0.470). Marked differences appeared for statements 4 and 5 .

Linkages with other stakeholders was characterized by similar correlations with all three types of benefits. Although these correlations are low, they reached a moderate impact on total benefits (0.415). The four statements presented to measure this factor (17-20) produced percentual differences that favored R.G.

\section{Discussion}

In response to the first specific research question, we now analyze the principle differences in the benefits obtained by S.B. and R.G. (Tables 3, 4). Of the Economic benefits, receiving "additional income" is a positive element for sustainability of ecotourism as stressed by Coria and Calfucura (2012). In this regard, the greater inclination of R.G. to add other economic activities has two explanations: first, a culture with a greater tendency towards independence and economic growth as can be seen in the diversification of activities performed there (Annex 1); and, second, better management of seasonal demand ("we no longer have null seasons", Survey 1). This finding supports the opinion of Das and Chatterjee (2015) that the seasonality of tourism income is not problematic if people learn how to combine it with other sources of income that, in turn, can derive in new jobs. Findings for S.B. in contrast, reveal a more conformist culture ("people here live day-to-day because they want to, they don't aspire to improve themselves because the land is so prodigious that it gives them all they need", Survey 6), and less effective management of seasonality ("there are periods of bonanza; those who know how to manage their money live quite well”, Survey 5).

With respect to the complementary benefits that the cooperatives make possible, the position of R.G. stands out, especially, for its regular distribution of profits. S.B., in contrast, does not offer such benefits, but only authorizes loans that are repaid by deducting money from members' earnings.

Regarding the generation of indirect (23) and direct employment (24), we can deduce that R.G.'s better position is related to its greater diversification of activities, which gives more people opportunities to participate in economic occupations (Annex 1). S.B., meanwhile, stands out for its lack of diversification ("the only route it offers is the one to Tovara (name of the tour) but it could offer more [and] could grow even more", Survey 6).

In terms of Social benefits, the higher employment of women (26) by R.G. is associated with the finding that members perform more activities that complement their excursions, so opportunities are greater for employing women, especially because they are granted, preferentially, to members' relatives.

R.G.'s higher position with respect to the improvement of work skills (27) concurs with observations of the factor Spaces for learning, where this cooperative is also in better standing, as will be shown below. Similarly, the finding that more members of R.G. fall into the high category in the analysis of their capacity to relate to other people (28) reflects greater social empowerment, also fostered by the Spaces for learning that strengthen feelings of cohesion and integration with the community, and build self-confidence and self-esteem, aspects observed by Scheyvens (1999), Fiorello and Bo (2012) and Ramos and Prideaux (2014).

In the area of Environmental benefits, the indicators analyzed successfully determined whether the control actions performed with respect to the environment are of a passive -i.e., only minimize negative impacts of tourism - or active character; that is, they contribute to enhancing the destination through positive transformations of the environment (Orams, 2001). Examples of passive actions include posting informative signs and cleaning up waste. An intermediate phase would include actions that entail greater human intervention, such as restoring flora and fauna. The active phase entails rigorous control of visitors by, for example, sanctioning inadequate actions, and greater demands on financial resources, such as investing in certification processes. According to our results (Table 4), R.G. can be placed in a 
position closer to the active phase of Orams' model (2001), because most of its actions correspond to the high category, as they exhibit greater participation in the positive transformation of the destination ("it is interesting to see how, through community work, it has been possible to enhance the beach area", Xaltembatv, 2017), and a willingness to continue improving ("when you try to get certified you have to give written evidence (...) they don't have a culture of registration but they've progressed a lot, they're willing to receive help", Interview1). S.B., in contrast, occupies a transitional position between the passive and active phases, with actions framed primarily in the medium category. This allows them to conserve the environment, but does not suggest any transformation of it ("for example, if you're going to enter a swimming hole (cenote) you shouldn't put on body cream because we're taking care of the marine fauna; but here [...] anyone can swim in the crocodile park with no restrictions", Interview 6).

Finally, R.G. proved to be more rigorous in the area of visitor awareness because it warns of inadequate actions and applies sanctions when necessary. Moreover, contrary to the case studied by Okasaki (2008), this cooperative does receive support from other local organizations to implement such measures, which fosters acceptance of established rules, while S.B. considers sufficient that its guides simply explain necessary precautions. One reference external to S.B. commented: "as service providers it's our obligation to perform educational labors among visitors (...) I think that's what's missing there" (Interview 7).

With regards to our research questions 2 and 3, we now elucidate the differences in the factors of participation (Table 5) and their relation to the benefits obtained (Table 6). For the factor Leadership, statement 6 allowed us to identify the leader's ability to motivate the group to grow through innovation. Here, S.B. reported a low identification of changes in its style of working. Specifically, respondents did not mention actions related to incorporating new visitor services or any modernization of the activities that would offer members new learning experiences. R.G., however, is characterized by greater awareness of transformations in their activities and styles of work, related to a search for, and training in, new ways of doing things: "They ask the National Commission of Natural Protected Areas to come in [that] drew our attention because usually the agency determines the areas that need to be protected" (Interview1). These transformations show the importance of the role of leaders and their determination to guide the group towards a certain work philosophy (Gunn and Var, 2002), especially since some members initially disapproved initiatives for change there, though once they began to see the results they came to understand their importance and contributed to those efforts (Interview1, Survey10).

Statement 7 evaluated the ability to share information and promote discussion and consensus among members. Although the directors of both cooperatives have certain decision-making faculties, S.B. exhibited greater disinformation regarding such decisions due to less contact between directors and members, many of whom only learn of recent events in the following assembly: "sometimes the board of directors has to act quickly, but at other times it should take everyone into account, not just two or three, and they've been told that" (Interview 25). In contrast, in R.G. we perceived a greater exchange of information because assemblies are held more often. Moreover, the directors can more easily call members in for informal dialogues because, in contrast to the members of S.B, most of them live in the area immediately around the office.

In summary, these two cooperatives exhibit distinct styles of leadership. In S.B. this is less innovative, more focused on resolving administrative issues, and notably infrequent in work areas, but based on the power conferred to act through authority and accords established in assemblies to apply sanctions to bring workers into line. We also observed a much less pro-active leadership group (Interview 7), so what stands out in the role of these directors is that they only motivate and coordinate members to perform routine activities. This leadership can be associated with the paternalist style and a power of convocation based on formality (Gray, 1989, cited by Jamal and Getz, 1995). This leadership style also reflects the posture that directors adopt towards a group that participates little in, and is largely unaware of, administrative and legal aspects.

Turning to the leadership style at R.G., it is more conciliatory in nature due to the existence of internal competition among members ${ }^{11}$ and more intense contact with them, which promotes dialogue (Survey10). Because R.G.'s directors work with a more pro-active group, they assume a key role in motivating them to adopt new forms of operating. As a result, their leadership is more closely associated with the participative style based on organizational goals and a power of convocation supported by trust (Gray, 1989, cited by Jamal and Getz, 1995). These differences allow us to understand that leadership is a key element for the level of economic and environmental benefits achieved, by acting as the channel that (i) conducts and motivates members to take on new challenges; (ii) promotes external relations that make it possible to improve management capacities; and (iii) facilitates flows of information and dialogue 
to establish agreements. Our results mirror Li's (2006) findings that highlight the importance of elite management balancing short and long-term benefits for the community in a Chinese biosphere reserve.

Regarding the factor Shared vision, S.B. has only a weak vision of growth through the incorporation of new services (Statement 14). Although S.B. broadened the bases of its constitution in 2015, most members do not share the new vision ("the vision of a few of us is to add tours", Survey 27). It may be that exposure to routine work in the absence of change ${ }^{12}$ has weakened projections of growth. Another pertinent fact is that S.B. is a recognized cooperative (Statement 15) that faces no threat of competition. This may be an additional factor that helps explain the lack of visualization of the need for changes.

In the case of R.G., the vision of change and growth is stronger ("if we don't change we're going to be left behind, in technology, in information [...] we need to advance, try new ways and if we make mistakes then we need to correct them" (Survey 16). At the same time, we observed greater awareness of external interests that could threaten their position as service providers: "it's important to offer better service so no business from somewhere else can enter" (Survey 3).

The strength of a shared vision is a key factor for increasing social and environmental benefits, that is reflected in the correlations but also materialized in the experience of R.G. where, unlike S.B., the transformations undertaken place members in a position of actors who are active in resolving community and environmental problems ("the cooperative invested to divide the docking sites with the idea of improving safety at the beach [...] the result in the first Easter Week was "zero accidents", Interview 1).

In terms of Spaces for learning, R.G. displays a more favorable scenario based on two findings: the greater exchange of perspectives and information fostered through more frequent meetings of members (Statement 10), which reinforces associativity (McCool, 2009); and contact with external advisers that promotes mechanisms for informing, training and generating new skills (Statements 9, 12): "the most important [aspect] of its transformation is that, with support from academic and governmental institutions, efforts have been, and still are, community-based" (Xaltembatv, 2017).

In S.B., in contrast, we found an obligation to participate in training related to members' main activity (obtaining official papers, learning first aid, etc.), but for other kinds of training members simply wait to be convoked with no firm obligation to attend. This reveals a weakness in incorporating objectives related to education: "we requested a specialized course for guides for bird-watching paid for by an Association that offers nature services, so there'd be no cost [...] [members] were invited but they didn't show up" (Interview 6).

This factor reveals the third key element for promoting greater benefits from ecotourism, with an accentuated effect on environmental benefits. Here, once again, R.G. evidenced better results thanks to the interaction between members and with external advisers.

Regarding the factor Evaluation of local assets, the differences found can be explained by mentioning two noteworthy situations: a) R.G. is stricter in caring for natural spaces, influenced by members' awareness of the damage that the island has suffered in the past and the importance of adopting rigorous measures to control visitors (Statement 1); and b) S.B. gives less recognition to the value of local history (Statement 2) as part of the "meaning of place", understood as the whole set of qualities that make a space unique and special (Murphy, 1985). This stands out because this tourist destination houses a rich collection of historical dates and events interwoven with the natural features of the reserve; but these are not exploited in discourse despite their potential for converting excursions into something much more special and memorable for visitors.

Comments gathered in S.B. included: "There's lots of young people who know the birds are getting scarcer, young people take you but don't explain anything" (Interview 6); and "Service providers should know the history of the area, the flora and fauna, the activities that develop there" (Interview 7). These observations reflect, on the one hand, that the value of local assets can be increased by fostering greater interaction between those who have the knowledge and those who provide services (Guevara, 1996). On the other, they underscore the importance of forms of community tourism that employ local knowledge and highlight the distinctive characteristics of the place, be they natural, historical or cultural (Murphy, 1985; Healey 1997; McCool, 2009; Innes and Booher, 2014). This factor fosters economic and environmental benefits, as is reflected in the correlations found. Clearly, demand for services at S.B. could be increased by valuing local assets and promoting rigorous control actions to care for local natural resources.

In Perception of individual and community benefits both cooperatives recognize that they generate benefits for the community in economic terms, but we found that the members of S.B. did not identify the ecological benefits generated through their work with the environment (Statement 4). R.G., in contrast, did identify the majority of those benefits. Moreover, awareness of the damage that 
tourism can cause (Statement 5) is greater in R.G., which leads members to assume a more active role in environmental care. The results for the two cooperatives show that awareness of these conditions can lead to a better understanding of the interdependence among actors and a desire of adequately manage natural resources for the collective good, in accordance with other research (Jamal and Getz, 1995; Guevara, 1996; Kernel, 2005). Clearly, this factor has an effect on environmental benefits.

For the factor of Linkages with other stakeholders the data from S.B. show a lower inclination towards external links when this entails collaboration in managing the natural reserve (Statements19, 20). However, they show a higher assessment of links that would allow them to increase their services, such as relations with restaurants and hotels (Statement 18). These linkages were identified in our interviews with external references, but simultaneously confirm that S.B. tends towards exclusivity in relation to other organisms: "I don't see it as being very inclusive, because they're jealous of possession [...] if they include other organizations they feel they'll risk losing something" (Interview7).

Conversely, R.G. exhibits a clearer inclination towards external linkages as it strives to enhance services and more adequately manage local natural resources. Thus, it maintains links with experts and government agencies for orientation in the conduction of its projects (Interview 1). There is also a sharper perception of the importance of networking with other actors in the community, and a more proactive attitude in addressing them (Surveys10, 11).

The local hotel association emphasizes the complementarity of its links with the cooperative. The latter wants to protect and promote the island, while the former is interested in increasing visits to this destination because promoting the island offers the advantage of attracting more tourists for longer stays. This highlights the interorganizational character of collaboration in tourism by stressing the value of cooperative work, where the sum of efforts can generate greater results than working in isolation, as noted by Nault and Stapleton (2011) in the case of remote ecotourism areas that maintain close links with external stakeholders; but informants pointed out, however, that this collaborative link has not always existed, being required mutual recognition that both sides were involved in a shared problematic and had common interests, issues identified by several scholars (Selin and Chávez, 1995; Kernel, 2005; Okasaki, 2008).

In summary, although both cooperatives have benefitted from external linkages, the fear of losing control has led S.B. to maintain a posture that is reluctant to accept collaborative links, one oriented towards a family-based strategy for managing the reserve. The experience of R.G., however, demonstrates that a strategy of collaboration with external actors can endow cooperatives with enhanced capacities to manage resources, while simultaneously strengthening its image in the community, a condition that, far from reducing organizational control, results in greater power (Keller cited by Jamal and Getz, 1995), so this factor provides an interesting result when balancing the three types of benefits.

Finally, in response to the fourth question, our multiple lineal regression analysis allows us to conclude that $65 \%$ of the total benefits of ecotourism can be explained by the multiple correlation of the factors analyzed above $\left(\mathrm{R}^{2}=0.65\right.$, $\mathrm{p}$-value $=0.000, \mathrm{~F}=7.661$, Durbin-Watson= 1.866$)$. This percentage is encouraging in terms of our ability to explain the causes of greater fulfilment of the objectives of ecotourism as a desired effect, considering that we are analyzing a complex phenomenon whose fulfilment is influenced by other factors not considered in this study.

In general, RG members show more active involvement than SB members. Moreover, the fact that the first cooperative shows better performance regarding benefits of ecotourism mirror other studies where community involvement directly relates to perceived benefits (Lee 2012). Our results also coincide with Sebele's (2010) conclusion that enhanced participation fosters the empowerment of people and increases local benefits, and with Das and Chatterjee (2015) and Obombo and Velarde (2019) findings stressing mutual interdependence between economic and social benefits of ecotourism and successful resource conservation.

\section{Conclusion}

Community participation in ecotourism management can enhance the achievement of its objectives. The theory of collaborative planning and the strategic focus of community tourism supply elements for understanding how collaborative decision-making processes function in settings of community management. This suggests, moreover, that certain factors are required for this kind of participation to be successful in terms of community empowerment. These factors are Evaluation of local assets, Perception of individual and community benefits, Leadership, Spaces for learning, Shared vision and Linkages with other stakeholders, all of which were examined for two community-managed tourism 
organizations. Our analysis clearly found that the stronger organization was the one that had higher indicators of active community participation, or empowerment, as several authors have suggested (Jamal and Getz, 1995; Guevara, 1996; Healey 1997; Kernel, 2005).

Upon comparing the economic, social and environmental benefits obtained through ecotourism in these two communities, we found that a scenario with better conditions in the factors of participation coincided with a higher evaluation of benefits. In addition, we were able to determine that the factors selected for in-depth analysis do, indeed, contribute effectively to increasing benefits. The most significant factor turned out to be Leadership due to its high correlation and capacity to potentiate the other factors that, in most cases, achieved moderate correlations with the benefits of ecotourism.

When we included these factors in a multiple lineal regression model to determine to what degree the total benefits achieved can be explained by multiple correlations among them, we calculated an index of $65 \%\left(\mathrm{R}^{2}\right)$ that justifies the conclusion that it is possible to potentiate achieving a broader range of objectives of ecotourism through community management by strengthening the condition of these factors of participation. These findings may well be replicable in other cases of community management in Mexico and countries with similar contexts, and so contribute to consolidating routes for promoting more inclusive economic institutions (Sosa and Contreras, 2018).

Our study has limitations. Measuring the sustainability of ecotourism is a complex issue, because it depends not only on what organizations can achieve within their sphere of action, nor exclusively on community participation ( $\mathrm{Li}, 2006)$; hence, our empirical evidence focuses on a set of key aspects. Moreover, the results should compared to other socioeconomic settings; therefore, we suggest to conduct comparative studies in other communities.

Community participation in ecotourism management presents a challenge due to even if there is a common interest among people, conflicts among diverse interests are ever-present in situations where people seek to construct consensus (Forester, 2012; Innes and Booher, 2014). However, if the discussions held during collaborative processes are visualized not as signs of weakness or threats to the celerity of decisions but, rather, as a way to arrive at more concrete solutions, then future research can more pragmatically center on discovering and/or developing mechanisms of effective participation in communities to increase the active involvement of more people.

\section{References}

Agüera, F. O. 2014. Turismo y cooperación al desarrollo: Un análisis de los beneficios del ecoturismo para los destinos. El Periplo Sustentable, (26), 47-66.

Ander-Egg, E. 2000. Métodos y técnicas de investigación social III. Como organizar el trabajo de investigación. Buenos Aires: Editorial Lumen.

Babbie, E. 2000. Fundamentos de la investigación social. México: Thompson Editores.

Blamey, R. 2001. Principles of ecotourism. In D. Weaver (Ed.), Encyclopedia of Ecotourism (pp. 5-22). Wallingford, UK: CAB International.

Cheung, H. 2015. Ecotourism as a multidisciplinary conservation approach in Africa. THERYA, 6(1), 31-41.

Clausen, H. B. and Gyimóthy, S. 2016. Seizing community participation in sustainable development: pueblos mágicos of Mexico. Journal of Cleaner Production, 111, 318-326.

Coria, J. and Calfucura, E. 2012. Ecotourism and the development of indigenous communities: The good, the bad, and the ugly. Ecological Economics, 73, 47-55.

Das, M. and Chatterjee, B. 2015. Ecotourism: A panacea or a predicament? Tourism Management Perspectives, 14, 3-16.

Fahmi, F.Z., Prawira, M.I., Hudalah, D. and Firman, T. 2016. Leadership and collaborative planning: The case of Surakarta, Indonesia. Planning Theory, 15(3) 294-315.

Fernández, A. M.J. 2011. Turismo comunitario y empresas de base comunitaria turísticas: ¿estamos hablando de lo mismo? El Periplo Sustentable, (20), 31-74.

Fiorello, A. and Bo, D. 2012. Community-based ecotourism to meet the new tourist's expectations: an exploratory study. Journal of Hospitality Marketing \& Management, 21(7), 758-778.

Forester, J. 2012. On the theory and practice of critical pragmatism: Deliberative practice and creative negotiations. Planning Theory, 12(1), 5-22.

Goodwin, H. 1996. In pursuit of ecotourism. Biodiversity and Conservation 5, 277-291

Guevara, J. R. Q. 1996. Learning through participatory action research for community ecotourism planning. Convergence, 29(3), 24-40. 
Gunn, C. A. and Var, T. 2002. Tourism Planning: Basics, concepts, cases. $4^{\text {th }}$ ed. New York: Routledge.

Hall, C. M. 1999. Rethinking collaboration and partnership: A public policy perspective. Journal of Sustainable Tourism, 7(3-4), 274-289.

Healey, P. 1997. Collaborative planning. Shaping places in fragmented societies. Vancouver: UBC Press.

INEGI, Instituto Nacional de Estadística y Geografía. Anuario estadístico y geográfico de Nayarit, 2017. Recovered 11 August 2017 from https:/ / www.inegi.org. $m x / a p p /$ biblioteca / ficha.html? upc =702825092054

Innes, J. E. and Booher, D. E. 2014. A turning point for planning theory? Overcoming dividing discourses. Planning Theory, 14(2), 195-213.

Jalani, J. O. 2012. Local people's perception on the impacts and importance of ecotourism in Sabang, Palawan, Philippines. Procedia-Social and Behavioral Sciences, 57, 247-254.

Jamal, T. B. and Getz, D. 1995. Collaboration theory and community tourism planning. Annals of Tourism Research, 22(1), 186-204.

Kernel, P. 2005. Creating and implementing a model for sustainable development in tourism enterprises. Journal of Cleaner Production, 13(2), 151-164.

Krüger, O. 2005. The role of ecotourism in conservation: panacea or Pandora's box? Biodiversity \& Conservation, 14(3), 579-600.

Lee, T. H. 2013. Influence analysis of community resident support for sustainable tourism development. Tourism Management, 34, 37-46.

Li, W. 2006. Community decision-making participation in development. Annals of Tourism Research, 33(1), 132-143.

López, P.G. and Palomino, V.B. 2014. Las empresas comunitarias de turismo naturaleza: factores de éxito y fracaso. Documento PPT. Recovered 10 May 2020 from https://docplayer.es/18869770-Las-empresas-comunitarias-de-turismo-naturaleza-factores-de-exito-y-fracaso.html

$\mathrm{McCool}$, S. F. 2009. Constructing partnerships for protected area tourism planning in an era of change and messiness. Journal of Sustainable Tourism, 17(2), 133-148.

Morera, D. 2008. Sinergias entre ecoturismo y desarrollo local en la Península de Osa, Costa Rica. Recovered from http://www.zobodat.at/stable/pdf/STAPFIA_0088_0755-0762.pdf

Murphy, P. 1985. Tourism: a community approach. London: Methuen.

Murphy, P. E. and Murphy, A. E. 2004. Strategic Management for Tourism Communities. Bridging the Gaps. England: Channel View Publications.

Nault, S. and Stapleton, P. 2011. The community participation process in ecotourism development: A case study of the community of Sogoog, Bayan-Ulgii, Mongolia. Journal of Sustainable Tourism, 19(6), 695-712.

Navarrete, J. M. 2000. El muestreo en la investigación cualitativa. Investigaciones sociales, 4(5), 165-180.

Obombo, M. K. and Velarde, V. M. 2019. El ecoturismo en las reservas de la biósfera: Prácticas y actitudes hacia la conservación. Pasos. Revista de Turismo y Patrimonio Cultural. 17(1), 97-112.

Okazaki, E. 2008. A Community-Based Tourism Model: Its conception and use. Journal of Sustainable Tourism, 16(5), 511-529.

Orams, M. B. 2001. Types of Ecotourism. In D. Weaver (Ed.), The Encyclopedia of Ecotourism (pp.23-36). Wallingford, UK: CAB International.

Orellana, S.E.E 2014. La gestión del desempeño social: una herramienta para la planeación participativa. En Gutiérrez, P.M. (Coord.), Planeación Participativa: Crítica, métodos y experiencias (pp. 195-207). Recovered from http://www.redcimas.org/wordpress/wp-content/uploads/2015/08/ LIBRO-PLANIFICACION-PARTICIPATIVA-13.pdf\#page=107

Ponce, A. A. 2012. La sustentabilidad como condición para el desarrollo de la Riviera Nayarit. En Arreola, Pacheco y Guevara (Coords.), Nayarit. Economía y Sociedad (pp. 361-374). Mexico: Universidad Autónoma de Nayarit.

Ramos, A. M. and Prideaux, B. 2014. Indigenous ecotourism in the Mayan rainforest of Palenque: empowerment issues in sustainable development. Journal of Sustainable Tourism, 22(3), 461-479.

Scheyvens, R. 1999. Ecotourism and the empowerment of local communities. Tourism Management, 20(2), 245-249.

Sebele, L. S. 2010. Community-based tourism ventures, benefits and challenges: Khama Rhino Sanctuary Trust, Central District, Botswana. Tourism Management, 31(1), 136-146.

SECTUR (Secretaría de Turismo) y UAN (Universidad Autónoma de Nayarit) 2014. Agenda de competitividad turistica Riviera Nayarit. Recovered 16 August 2017 from http://www.sectur.gob.mx/ wp-content/uploads /2015/02/PDF-Riviera-Nayarit.pdf 
Selin, S. and Chávez, D. 1995. Developing an evolutionary tourism partnership model. Annals of Tourism Research, 22(4), 844-856.

Sosa, M.C. and Contreras, L.M.R 2018. Ecoturismo como vía al desarrollo sostenible. Análisis crítico de su fracaso en países no desarrollados y propuesta para su gestión. En Carrillo, Ramírez y Molinar (Coords.), Emprendimientos e iniciativas turísticas, casos en México (pp. 143-162). Recovered from http://ww.ucol.mx/content/publicacionesenlinea/adjuntos/Emprendimientos-e-iniciativas-turisticas_472.pdf.

Sosa, M.C. 2018. Planeación estratégica comunitaria para la integración de objetivos del ecoturismo. Caso: cooperativas turísticas de la Riviera Nayarit (Unpublished Doctoral Dissertation). Universidad de Occidente, Mexico.

Taylor, G. 1995. The community approach: Does it really work? Tourism Management, 16(7), 487-489.

Tosun, C. 2006. Expected nature of community participation in tourism development. Tourism Management, 27(3), 493-504.

Vargas del Río, D. and Brenner, L. 2013. Ecoturismo comunitario y conservación ambiental: la experiencia de La Ventanilla, Oaxaca, México. Estudios Sociales, 21(41), 32-63.

Xaltembatv 29 October 2017. Isla del coral, el proyecto. (Video archive). Consulted 20 May 2018 at https: / / www.youtube.com / watch? $v=b k F n m s p 735 Y \& t=6 s$

\section{Notes}

See Annex 1.

2 See the list of surveys and interviews in Annex 3. We attempted to apply a census; however, despite of our efforts it was not possible to dialogue with the 21 members of each cooperative, the reasons included: temporary residence in another city; refusal to participate; and unavailability due to illness. However, 16 surveys were considered sufficient as they represent $76.19 \%$ of members.

3 Annex 2 contains additional information on the design of the survey and procedures of the scale adjustment. See Annex 2C., statements 1-20.

4 See Annex 2C., questions 21-34.

5 This test quantifies the difference of means between the case studies; however, as it is a non-parametric study, it does not apply population parameters such as Standard Deviation (SD).

6 These tests were applied for the variables Age, Length of service and Education -Gender was not considered due to the small number of women- in order to assess possible influences on responses; however, no-statistically significant results were found. Because the sociodemographic profile is not relevant in our analysis, we omit it from results; however, it can be consulted in Annex 1.

7 The normality of data required for the t test and Pearson correlation was demonstrated via Normal Q-Q Graph. The requirement of equality of variance was evaluated using the Levene test, where a p-value $>.05$ permits assuming this equality. The p-values obtained were: participation factors.972, strategic principles.805, economic benefits.801, social benefits.602, environmental benefits.712.

8 Annex 3 summarizes codes.

9 Annex 2B. Systematization of the indices.

10 Annex 2A. Construction and significance of the indicators.

11 The form of working and distributing income at R.G. stimulates internal competition among members, because each one receives his income for the excursions performed. In the case of S.B, at the end of the day income is divided up among all members, regardless of who actually provided the services.

12 See the analysis of Leadership.

Annex 1

Characteristics for the comparison of the studies case

\begin{tabular}{|l|l|l|}
\hline \multicolumn{1}{|c|}{ Characteristic } & \multicolumn{1}{c|}{ San Blas } & \multicolumn{1}{c|}{ Rincón de Guayabitos } \\
\hline Juridical organization & Cooperative & Cooperative \\
\hline Initiative for formation & Communitarian & Communitarian \\
\hline Decision-making & $\begin{array}{l}\text { General assembly: includes all members; the maximum authority for } \\
\text { establishing accords; quorum is 2/3 of members, each with the right } \\
\text { to one vote; decisions adopted by majority vote. } \\
\text { Administrative Council: formed by the president, secretary and } \\
\text { treasurer; the organ of execution and representation; can take some } \\
\text { decisions as stipulated by law and the assembly; e.g., purchases that } \\
\text { do not exceed a certain monetary limit. }\end{array}$ \\
\hline
\end{tabular}




\begin{tabular}{|c|c|c|}
\hline Characteristic & San Blas & Rincón de Guayabitos \\
\hline $\begin{array}{l}\text { Sociodemographic profile of } \\
\text { cooperative members }\end{array}$ & $\begin{array}{l}55 \text { years old, } 21 \text { years of service, } \\
69 \% \text { male and } 31 \% \text { female, } 56 \% \\
\text { married and } 25 \% \text { widowed. Level } \\
\text { education: } 37.5 \% \text { incomplete } \\
\text { basic, } 12.5 \% \text { complete basic, } 31 \% \\
\text { upper middle, } 6 \% \text { had a high } \\
\text { school degree and } 13 \% \text { formal } \\
\text { professional skills. } 62.5 \% \text { always } \\
\text { lived in the community and } 88 \% \\
\text { own a home. }\end{array}$ & $\begin{array}{l}39 \text { years old, } 17 \text { years of service, } \\
100 \% \text { male, } 12.5 \% \text { single, } 25 \% \\
\text { married, } 12.5 \% \text { widower, } 50 \% \\
\text { cohabiting. Level of education: } \\
25 \% \text { incomplete basic, } 56 \% \\
\text { complete basic, } 19 \% \text { upper } \\
\text { middle. } 69 \% \text { always lived in the } \\
\text { community and } 88 \% \text { own a home. }\end{array}$ \\
\hline $\begin{array}{l}\text { Nature-based tourism } \\
\text { (Blamey, 2001; Das and } \\
\text { Chatterjee, 2015, Jalani, 2012) }\end{array}$ & $\begin{array}{l}\text { Boat trips year-round through } \\
\text { the wetlands and mangroves; } \\
\text { observation of migratory birds } \\
\text { from December to March. }\end{array}$ & $\begin{array}{l}\text { Boat trips on the ocean, scuba- } \\
\text { diving, snorkeling and sport } \\
\text { fishing year-round; observation of } \\
\text { humpback whales from December } \\
\text { to March. }\end{array}$ \\
\hline $\begin{array}{l}\text { Conservation activities } \\
\text { (Vargas del Rio and Brenner, } \\
\text { 2013; Agüera, 2014 ) }\end{array}$ & $\begin{array}{l}\text { Natural area declared a Ramsar } \\
\text { site; cleaning water currents; } \\
\text { reforestation of the mangrove; } \\
\text { verbal explanations of measures } \\
\text { to avoid affecting flora and fauna; } \\
\text { recipients for classifying waste. }\end{array}$ & $\begin{array}{l}\text { Natural area protected by the } \\
\text { community; maintenance of } \\
\text { certified beach on an island } \\
\text { and of a barrier to prevent its } \\
\text { erosion; ban on extracting coral, } \\
\text { flora and fauna; ban on entering } \\
\text { with bottles and other glass } \\
\text { containers; banners and verbal } \\
\text { explanations of precautionary } \\
\text { measures and importance of not } \\
\text { using solar protectors or solvent- } \\
\text { based tanning agents; recipients } \\
\text { for classifying waste; ban on } \\
\text { fishing within a 5-km radius; } \\
\text { control of fishers in the area. }\end{array}$ \\
\hline $\begin{array}{l}\text { Complementary } \\
\text { Activities. } \\
\text { (Coria and Calfucura, 2009; } \\
\text { Blamey, 2001) }\end{array}$ & $\begin{array}{l}\text { Sales of regional products, snacks } \\
\text { and beverages. }\end{array}$ & $\begin{array}{l}\text { On the island: rental of chairs, } \\
\text { tables, scuba and snorkeling } \\
\text { gear; professional scuba-diving } \\
\text { guide; sales of professional photos } \\
\text { taken while scuba-diving; sales of } \\
\text { snacks and beverages; restaurant. } \\
\text { In R.G: trips on banana boats, } \\
\text { rental of jet skis. }\end{array}$ \\
\hline $\begin{array}{l}\text { Long-term operation } \\
\text { (Blamey, 2001; Murphy, 1985) }\end{array}$ & $\begin{array}{l}\text { Over } 40 \text { years according to } \\
\text { testimony by founding members. }\end{array}$ & 42 years, since its Constitution. \\
\hline $\begin{array}{l}\text { No. of members } \\
\text { (Murphy and Murphy, 2004; } \\
\text { Jamal and Getz, 1995) }\end{array}$ & $\begin{array}{l}21 \text { members (average age } 55 \\
\text { years) } \\
11 \text { direct, } 6 \text { indirect workers. }\end{array}$ & $\begin{array}{l}21 \text { members (average age } 39 \\
\text { years). } \\
60 \text { direct, } 30 \text { indirect workers, } 20 \\
\text { seasonal laborers }\end{array}$ \\
\hline $\begin{array}{l}\text { Location close to important } \\
\text { tourism center }(<150 \mathrm{~km}) \text { and } \\
\text { connecting routes to access the } \\
\text { destination. } \\
\text { (Jamal and Getz, 1995; Murphy, } \\
\text { 1985) }\end{array}$ & $\begin{array}{l}\text { Located } 140 \mathrm{~km} \text { from Nuevo } \\
\text { Vallarta, a tourist destination } \\
\text { located } 12 \mathrm{~km} \text { from the } \\
\text { international airport. } \\
\text { Highway connection, public and } \\
\text { private transport available. }\end{array}$ & $\begin{array}{l}\text { Located } 60 \mathrm{~km} \text { from Nuevo } \\
\text { Vallarta. } \\
\text { Highway connection, public and } \\
\text { private transport available. }\end{array}$ \\
\hline
\end{tabular}

Source: elaborated by the authors. 


\section{Annex 2}

\section{A. Construction and meaning of indicators for measuring benefits of ecotourism}

The precision and reliability adjustment of the measurement scale covered a series of steps: 1 . Expert evaluation, 2. Pilot test of the instrument, 3. Elimination of reagent with less variability in each dimension, 4. Analysis of the correlations "reactive - total dimension" discarding those that correlate less than 0.35, 5. Cronbach's Alpha (AdC) calculation for each dimension.

At the end of the adjustment procedure, the reagents that remain in the analysis are: Participation factors $=18, \mathrm{AdC}=0.862 ;$ Strategic principles $=7, \mathrm{AdC}=0.646 ;$ Economic benefits $=4, \mathrm{AdC}=0.603$; Social benefits $=5, \mathrm{AdC}=0.649$; Environmental benefits $=5, \mathrm{AdC}=0.604 ;$ Total benefits $=14, \mathrm{AdC}$ $=0.844$. Appendix $\mathrm{C}$ of this Annex shows a partial presentation of the final format applied during fieldwork, the factors that did not turn out to be significant after statistical testing have been omitted.

\begin{tabular}{|c|c|}
\hline \multicolumn{2}{|c|}{ Economic benefits } \\
\hline 21 & $\begin{array}{l}\text { Refers to whether the member performs another economic activity apart from the } \\
\text { cooperative. Accompanied by an open question to indicate if income received through } \\
\text { the cooperative is sufficient to satisfy basic needs. }\end{array}$ \\
\hline 22 & $\begin{array}{l}\text { Complementary benefits promoted by the cooperative for its members apart from } \\
\text { the income received through work, but that directly impacts the household economy } \\
\text { through support for obtaining goods and services, given that cooperatives can } \\
\text { constitute funds to assist their members. }\end{array}$ \\
\hline 23 & $\begin{array}{l}\text { Generation of indirect employment to ascertain to what degree the cooperative's } \\
\text { existence has fostered economic activity for friends and others members of the } \\
\text { family. }\end{array}$ \\
\hline 24 & $\begin{array}{l}\text { Generation of direct employment to ascertain to what degree the cooperative has } \\
\text { provided employment to each member's direct nuclear family. }\end{array}$ \\
\hline \multicolumn{2}{|c|}{ Social benefits } \\
\hline 25 & Measures members' perceptions of the just and equitable distribution of income. \\
\hline 26 & $\begin{array}{l}\text { Measures the number of women (members of cooperative or not) that work and } \\
\text { obtain economic income through the cooperative. }\end{array}$ \\
\hline 27 & $\begin{array}{l}\text { Measures real improvement in work skills acquired through training sponsored by } \\
\text { the cooperative. }\end{array}$ \\
\hline 28 & $\begin{array}{l}\text { Identifies to what degree participating in the cooperative helps members improve } \\
\text { their capacity to relate to other people in general, understood as the result of their } \\
\text { involvement in, and information and abilities acquired through it, allowing them } \\
\text { to gain confidence in links with others and generate a tendency towards greater } \\
\text { involvement in the community (Das and Chatterjee, 2015). }\end{array}$ \\
\hline 29 & $\begin{array}{l}\text { Identifies to what degree the cooperatives have supported projects for social or } \\
\text { community benefit as part of their commitment with the social environment to } \\
\text { which they belong. }\end{array}$ \\
\hline \multicolumn{2}{|c|}{ Environmental benefits } \\
\hline 30 & Identifies the cooperatives' actions to prevent environmental pollution by visitors \\
\hline 31 & Measures improvement of members' and workers' capacity to care for nature. \\
\hline 32 & $\begin{array}{l}\text { Identifies actions that contribute to improving the natural spaces where activities } \\
\text { are performed; positive transformation of the surroundings. }\end{array}$ \\
\hline 33 & $\begin{array}{l}\text { Measures the degree of monetary contributions by members for the maintenance or } \\
\text { restoration of nature. }\end{array}$ \\
\hline 34 & $\begin{array}{l}\text { Identifies actions by the cooperative to raise the consciousness of tourists regarding } \\
\text { how to care for natural resources. }\end{array}$ \\
\hline
\end{tabular}




\section{B. Systematization of the indices}

\begin{tabular}{|l|l|l|l|}
\hline \multicolumn{2}{|c|}{$\begin{array}{c}\text { Human and organizational factors of } \\
\text { participation }\end{array}$} & \multicolumn{1}{c|}{ Economic, social and environmental benefits } \\
\hline \multicolumn{1}{|c|}{ Index } & \multicolumn{1}{c|}{ Condition } & \multicolumn{1}{c|}{ Index } & \multicolumn{1}{c|}{ Condition } \\
\hline$>80 \%$ & Very favorable & $>80 \%$ & Very high \\
\hline$>60 \% \leq 80 \%$ & Favorable & $>60 \% \leq 80 \%$ & High \\
\hline$>40 \% \leq 60 \%$ & Moderate & $>40 \% \leq 60 \%$ & Moderate \\
\hline$>20 \% \leq 40 \%$ & Unfavorable & $>20 \% \leq 40 \%$ & Low \\
\hline$>0.00 \% \leq 20 \%$ & Very unfavorable & $>0.00 \% \leq 20 \%$ & Very low \\
\hline
\end{tabular}

Note: this scale is used to give a final reading to the scores obtained for each benefit and factor; the percentages were calculated by totaling the normalized scores.

\section{SURVEY}

Member of cooperative S.B. [ ]

R.G. []

On this list of statement, mark the box that correspond to the respondent's opinion.

\begin{tabular}{|c|c|c|c|c|c|}
\hline A) PARTICIPATION FACTORS & $\begin{array}{c}\text { Totally } \\
\text { disagree }\end{array}$ & Disagree & Unsure & Agree & $\begin{array}{c}\text { Totally } \\
\text { agree }\end{array}$ \\
\hline \multicolumn{6}{|l|}{ Evaluation of local assets } \\
\hline \multicolumn{6}{|l|}{$\begin{array}{l}\text { 1. It is not necessary to ask the tourists } \\
\text { to observe specific care measures during } \\
\text { excursions, because there are no actions } \\
\text { that could significantly damage nature. }\end{array}$} \\
\hline \multicolumn{6}{|l|}{$\begin{array}{l}\text { 2. During excursions, it is very important } \\
\text { to tell tourists stories and narrate local } \\
\text { history related to the sites they visit. }\end{array}$} \\
\hline \multicolumn{6}{|l|}{$\begin{array}{l}\text { 3. Only a limited number of people should } \\
\text { participate in excursions because the } \\
\text { ecosystem could be affected. }\end{array}$} \\
\hline $\begin{array}{l}\text { Perception of individual and } \\
\text { community benefits }\end{array}$ & $\begin{array}{l}\text { Totally } \\
\text { disagree }\end{array}$ & Disagree & Unsure & Agree & $\begin{array}{c}\text { Totally } \\
\text { agree }\end{array}$ \\
\hline \multicolumn{6}{|l|}{$\begin{array}{l}\text { 4. In this cooperative we obtain personal } \\
\text { and collective benefits because our actions } \\
\text { also benefit the community (if answered } \\
\text { affirmatively, ask what aspects they } \\
\text { consider benefit the community and write } \\
\text { them in the next box). }\end{array}$} \\
\hline \multicolumn{6}{|l|}{$\begin{array}{l}\text { 5. Tourism is not always positive; it } \\
\text { can also have negative effects on the } \\
\text { community. }\end{array}$} \\
\hline Leadership & $\begin{array}{c}\text { Totally } \\
\text { disagree }\end{array}$ & Disagree & Unsure & Agree & $\begin{array}{c}\text { Totally } \\
\text { agree }\end{array}$ \\
\hline \multicolumn{6}{|l|}{$\begin{array}{l}\text { 6. We have performed the same activities } \\
\text { in the same way for a long time, with no } \\
\text { great changes in our way of working. }\end{array}$} \\
\hline $\begin{array}{l}\text { 7. The directors never take a decision } \\
\text { without first positing it for consideration } \\
\text { by all members. }\end{array}$ & & & & & \\
\hline
\end{tabular}




\begin{tabular}{|c|c|c|c|c|c|}
\hline \multicolumn{6}{|l|}{$\begin{array}{l}\text { 8. The directors constantly encourage the } \\
\text { group to improve our skills in attending to } \\
\text { and serving visitors. }\end{array}$} \\
\hline Spaces for learning & & & & & \\
\hline $\begin{array}{l}\text { 9. Only a few members attend training } \\
\text { events when they are offered. }\end{array}$ & & & & & \\
\hline $\begin{array}{l}\text { 10. It's good to participate in assemblies } \\
\text { because it helps improve our ability to } \\
\text { propose solutions and make decisions, }\end{array}$ & & & & & \\
\hline $\begin{array}{l}\text { 11. The cooperative is not demanding in } \\
\text { terms of the training of members; people } \\
\text { who want training receive it, those who } \\
\text { aren't interested don't. }\end{array}$ & & & & & \\
\hline $\begin{array}{l}\text { 12. We have two or more training events } \\
\text { every year. }\end{array}$ & & & & & \\
\hline B) STRATEGIC PRINCIPLES & $\begin{array}{l}\text { Totally } \\
\text { disagree }\end{array}$ & Disagree & Unsure & Agree & $\begin{array}{c}\text { Totally } \\
\text { agree }\end{array}$ \\
\hline Shared vision & & & & & \\
\hline $\begin{array}{l}\text { 14. One of the cooperative's principle goals } \\
\text { is to improve constantly through changes } \\
\text { in our way of working and by integrating } \\
\text { new services. }\end{array}$ & & & & & \\
\hline $\begin{array}{l}\text { 15. it is very important that in the future } \\
\text { this cooperative be recognized as the } \\
\text { principle local supplier of excursions } \\
\text { (elaborate your views on this thought). }\end{array}$ & & & & & \\
\hline $\begin{array}{l}\text { 16. Our mission as a local tourism } \\
\text { cooperative is to ensure at all times that } \\
\text { natural spaces are not damaged (if they } \\
\text { agree, ask if they consider the role of the } \\
\text { cooperative to be very important in this } \\
\text { regard and why). }\end{array}$ & & & & & \\
\hline Links with other stakeholders & $\begin{array}{l}\text { Totally } \\
\text { disagree }\end{array}$ & Disagree & Unsure & Agree & $\begin{array}{c}\text { Totally } \\
\text { agree }\end{array}$ \\
\hline $\begin{array}{l}\text { 17. The cooperative should not maintain } \\
\text { any links with government because it only } \\
\text { takes advantage of us through taxation } \\
\text { without providing any benefits. }\end{array}$ & & & & & \\
\hline $\begin{array}{l}\text { 18. We often participate in work meetings } \\
\text { with other people from the tourism sector } \\
\text { to analyze the conditions of our activity } \\
\text { and agree on action policies. }\end{array}$ & & & & & \\
\hline $\begin{array}{l}\text { 19. It is not in our best interest to } \\
\text { collaborate with other organizations } \\
\text { because it is preferable to maintain our } \\
\text { independence and exclusivity in the } \\
\text { management of natural resources. }\end{array}$ & & & & & \\
\hline
\end{tabular}


20. Elaborating a plan or program for ecotourism development requires linking the cooperative to other actors; for example, other local businesses, government and NGOs.

\section{C) BENEFITS OF ECOTOURISM}

\section{ECONOMIC}

21. Do you perform another economic activity in addition to the cooperative? (If the response is 'Yes', ask why).

1. No, 2. Sometimes, 3.Yes

Why?

22. How often has the cooperative offered some type of support to help your family obtain school materials, clothes and shoes, articles for the home, food baskets, education, medical care or medicines, support for funeral costs, commutes, etc.?

23. How many relatives and friends of the members of the cooperative have benefitted economically by providing services that are complementary to excursions, such as accommodation, selling food and beverages, renting tables and chairs, renting umbrellas, selling regional souvenirs, selling candy or sweets, selling ice, renting accessories for excursions, etc.?

24. Aside from yourself, how many members of your family work directly for and receive regular income from the cooperative?

1. Never 2. On some occasions 3. On many occasions
1. A few, 2. Plenty, 3. Many

1. None, 2. One, 3. Two or more

\section{SOCIAL}

25. Do you consider that the cooperative facilitates a fair and equitable distribution of income among members, with each one receiving what is due to her/him in relation to their effort and contribution?

26. How many women (members or not) work with, and obtain income economic through, the cooperative?

27. How many members have succeeded in improving their work skills through training provided by the cooperative?

28. To what degree has your participation in the cooperative helped you achieve better links to and relations with other people?

29. How often has the cooperative authorized resources to support projects of social or community benefit?

1. No, 2. Not sure, 3. Yes

1. $1-5,2.6-10,3.10$ or more

1. Some, 2. The majority, 3. All

1. Almost nothing, 2. Plenty, 3. A lot

1. Never, 2. Sometimes 3. Many times

\section{ENVIRONMENTAL}

30. Which of the following actions are performed to prevent environmental pollution? (multiple choice)

a. Informative banners; b. Cleaning up the waste left behind by visitors; c. Limitating the articles that tourists can introduce into natural spaces (glass, solvents, plastics, perfumes, etc.) (value with 1, 2 or 3 depending on the number of options marked).

31. Over time, how many members and workers of the cooperative have improved their ability to care for nature?

1. Some, 2. The majority, 3. All

32. Which of the following actions are performed to improve the natural spaces where your activities are carried out? (multiple choice) 
a. Cleaning water currents and contaminated land; b. Restoring flora and/or fauna, c. Obtaining certifications of quality for our services

33. Have you ever made monetary contributions as a member, destined exclusively for the care or restoration of natural resources?

34. What means are used to inform tourists about, and make them aware of, caring for natural spaces? (multiple choice)

a. Informative banners and pamphlets; $b$. Detailed explanations by guides of the measures taken inside the Reserve; c. Warning/sanctioning tourists for inadequate actions.

35. In your point of view, is there sufficient trust and collaboration among all members?

36. When it is necessary to perform an activity outside normal working hours or roles, do people get

37. Would you say that the leaders/directors succeed in motivating the group to commit to carrying out certain activities?

38. Are all the members of the cooperative interested in innovating and striving to find the best ways of getting things done?

Annex 3

List of surveys applied and interviews conducted

\begin{tabular}{|c|c|c|c|c|c|}
\hline \multicolumn{6}{|c|}{ Current members of the cooperatives } \\
\hline & $\begin{array}{c}\text { Cooperative } \\
\text { R.G. }\end{array}$ & Date & & $\begin{array}{c}\text { Cooperative } \\
\text { S.B. }\end{array}$ & Date \\
\hline Member1 & Survey1 & $20 / 11 / 2017$ & Member1 & Survey17 & $5 / 12 / 2017$ \\
\hline Member2 & Survey2 & $20 / 11 / 2017$ & Member2 & Survey18 & $5 / 12 / 2017$ \\
\hline Member3 & Survey3 & $20 / 11 / 2017$ & Member3 & Survey19 & $5 / 12 / 2017$ \\
\hline Member4 & Survey 4 & $21 / 11 / 2017$ & Member4 & Survey20 & $6 / 12 / 2017$ \\
\hline Member5 & Survey5 & $21 / 11 / 2017$ & Member5 & Survey21 & $6 / 12 / 2017$ \\
\hline Member6 & Survey6 & $21 / 11 / 2017$ & Member6 & Survey22 & $6 / 12 / 2017$ \\
\hline Member7 & Survey7 & $22 / 11 / 2017$ & Member7 & Survey23 & $6 / 12 / 2017$ \\
\hline Member8 & Survey8 & $22 / 11 / 2017$ & Member8 & Survey24 & $7 / 12 / 2017$ \\
\hline Member9 & Survey9 & $23 / 11 / 2017$ & Member9 & Survey25 & $8 / 12 / 2017$ \\
\hline Member10 & Survey10 & $23 / 11 / 2017$ & Member10 & Survey26 & $8 / 12 / 2017$ \\
\hline Member11 & Survey11 & $23 / 11 / 2017$ & Member11 & Survey27 & $10 / 12 / 2017$ \\
\hline Member22 & Survey12 & $24 / 11 / 2017$ & Member22 & Survey28 & $10 / 12 / 2017$ \\
\hline Member13 & Survey13 & $25 / 11 / 2017$ & Member13 & Survey29 & $10 / 12 / 2017$ \\
\hline Member14 & Survey14 & $27 / 11 / 2017$ & Member14 & Survey30 & $15 / 12 / 2017$ \\
\hline Member15 & Survey15 & $29 / 11 / 2017$ & Member15 & Survey31 & $17 / 12 / 2017$ \\
\hline Member16 & Survey16 & $30 / 11 / 2017$ & Member16 & Survey32 & $17 / 12 / 2017$ \\
\hline \multicolumn{6}{|c|}{ External informants } \\
\hline $\begin{array}{l}\text { President, } \\
\text { Secretary } \\
\text { and Event } \\
\text { Director, Hotel } \\
\text { Association, } \\
\text { Compostela }\end{array}$ & Interview1 & $25 / 11 / 2017$ & Local resident & Interview5 & $12 / 12 / 2017$ \\
\hline Local resident & Interview2 & $27 / 11 / 2017$ & $\begin{array}{l}\text { President, Hotel } \\
\text { Association, S.B }\end{array}$ & Interview6 & $13 / 12 / 2017$ \\
\hline
\end{tabular}




\begin{tabular}{|l|l|l|l|l|l|}
\hline $\begin{array}{l}\text { Assistant, Port } \\
\text { Captaincy }\end{array}$ & Interview3 & $28 / 11 / 2017$ & $\begin{array}{l}\text { Analyst, } \\
\text { National PNA } \\
\text { Commission }\end{array}$ & Interview7 & $12 / 12 / 2017$ \\
\hline $\begin{array}{l}\text { Local resident } \\
\text { and street } \\
\text { vendor }\end{array}$ & Interview4 & $30 / 11 / 2017$ & $\begin{array}{l}\text { Municipal } \\
\text { Tourism Office }\end{array}$ & Interview8 & $11 / 12 / 2017$ \\
\hline
\end{tabular}

\section{List of codes used for qualitative analysis}

\begin{tabular}{|c|c|}
\hline Code & Description \\
\hline 1. Economic activity in the community / Changes & \multirow{7}{*}{$\begin{array}{l}\text { They correspond to questions } \\
\text { that focus on impact of tourist } \\
\text { development and ecotourism in the } \\
\text { community }\end{array}$} \\
\hline 2. Community transformations & \\
\hline 3. Employment opportunities from tourism & \\
\hline 4. Hunting of animals and felling of trees / Control & \\
\hline 5. Benefit of tourism for low-income people & \\
\hline 6. Tourism income in relation to another activity & \\
\hline 7. Perception of negative tourism / Impacts on the community & \\
\hline 8. Changes in nature tourism & \multirow{7}{*}{$\begin{array}{l}\text { They correspond to questions that } \\
\text { focus on the destination conditions } \\
\text { and the role of the various actors }\end{array}$} \\
\hline 9. Changes in natural spaces, flora and fauna & \\
\hline 10. Environmental conservation initiatives & \\
\hline 11. Support for conservation initiatives & \\
\hline 12. People benefited from a protected nature reserve & \\
\hline 13. Training opportunity for nature tourism & \\
\hline 14. Type of training support & \\
\hline 15. Nature-friendly excursion & \multirow{11}{*}{$\begin{array}{l}\text { They correspond to questions that } \\
\text { focus on performance of the tourist } \\
\text { cooperatives and their linkage } \\
\text { with other actors }\end{array}$} \\
\hline 16. Contribution to natural resources care & \\
\hline 17. Organization of service / tourist complaints. & \\
\hline 18. Excursion conducted by local residents & \\
\hline 19. Harmony and cooperation with the community & \\
\hline 20. Complaints from local residents & \\
\hline 21. Managing relationships and conflict with local residents & \\
\hline 22. Socially responsible company & \\
\hline 23. Support for community benefit initiatives & \\
\hline 24. Cooperative links & \\
\hline 25. Qualification of the cooperative's work & \\
\hline
\end{tabular}

Recibido: 